\title{
Xanthomonas translucens from Small Grains: Diversity and Phytopathological Relevance
}

\author{
C. Bragard, E. Singer, A. Alizadeh, L. Vauterin, H. Maraite, and J. Swings
}

First and fifth authors: Unité de Phytopathologie, UCL, Place Croix du Sud, 2bte3 B-1348 Louvain-la-Neuve, Belgium; second, fourth, and sixth authors: Laboratorium voor Microbiologie, RUG, Rijksuniversiteit Gent, K.L. Ledeganckstraat, 35 B-9000 Gent, Belgium; and third author: Laboratoire de Phytopathologie, ENSAT, Avenue de Muret, 145, F-31076 Toulouse cedex, France. Accepted for publication 18 July 1997.

\begin{abstract}
Bragard, C., Singer, E., Alizadeh, A., Vauterin, L., Maraite, H., and Swings, J. 1997. Xanthomonas translucens from small grains: Diversity and phytopathological relevance. Phytopathology 87:1111-1117.

Sixty-eight presumptive Xanthomonas translucens strains isolated from 15 small grains or grass species were studied by pathogenicity tests on barley, bread wheat, oat, and bromegrass species, and also by AFLP, analysis of fatty acid methyl esters (FAME), and sodium dodecyl sulfate-polyacrylamide gel electrophoresis of protein extracts. The $X$. translucens strains were divided into three pathogenicity types based on differences observed on barley and bread wheat. Two unspeciated strains producing atypical symptoms formed a fourth pathogenicity type. Pathogenicity on

oat and bromegrass species varied within these types. Clusterings observed by AFLP analysis and, to a lesser extent, by FAME analysis were consistent with these pathogenicity groupings. The current results, as well as those of previous restriction fragment length polymorphism analyses of the same strains, support the recent reclassification of $X$. translucens pv. translucens and $X$. translucens pv. hordei as true synonyms. $X$. translucens pv. cerealis, $X$. translucens pv. translucens, and X. translucens pv. undulosa cluster in different groups by AFLP and FAME analyses. Even though distinction by simple biochemical tests is not clear-cut, the data indicate that the pathovars cerealis, translucens, and undulosa correspond to true biological entities.
\end{abstract}

Bacterial leaf streak (BLS) is the most important bacterial seedborne disease of wheat and other small grains grown in warm and humid climates. It is considered to be caused by five of the former Xanthomonas campestris pathovars (pv. cerealis, pv. hordei, pv. secalis, pv. translucens, and pv. undulosa) that are often grouped together under the name 'translucens group' (39) or even considered as a single species or pathovar named $X$. translucens or $X$. campestris pv. translucens $(11,22,23)$.

Recently, Vauterin et al. (35) proposed the name $X$. translucens sp. nov. nom. rev. based on a systematic and comprehensive polyphasic approach. The proposed species includes both the pathovars arrhenatheri, graminis, phlei, phleipratensis, and poae, which are pathogenic for various Poaceae, and the pathovars of the "translucens group.' Names, at the infraspecific level, of the 10 different former pathovars were retained according to phytopathological practice, because the relevance of the host specificity was not clear.

From practical, economical, and phytopathological points of view, there is a real need for a strict differentiation of the bacterial strains at the pathogenicity level, as recently demonstrated by the case of $X$. axonopodis pv. citri and the bacterial leaf spot disease in Florida (30). The danger represented by strains causing BLS of wheat is of much more concern for wheat-growing areas than the risk of outbreaks of $X$. translucens pv. arrhenatheri, $X$. translucens $\mathrm{pv}$. graminis, or $X$. translucens pv. poae.

The practice of naming a pathovar on the basis of the "host from which first isolated' instead of on the basis of a differential host range study, the lack of clear definitions, and the use of various pathogenicity testing methods has led to a confused taxonomy for the 'translucens group' $(8,15,32)$.

BLS was first described for barley isolates by Jones et al. (21). Unlike the first described isolates, strains from wheat were shown

Corresponding author: C. Bragard; E-mail address: bragard@ fymy.ucl.ac.be

Publication no. P-1997-0908-02R

(C) 1997 The American Phytopathological Society to be pathogenic for wheat and also for barley; associated with black chaff symptoms, the bacterium was originally called Bacterium translucens var. undulosa (29). Later, xanthomonads isolated from rye were believed to be specific to this plant species and named Bacterium translucens var. secalis (26). The host range for some isolates from wheat, rye, and barley was shown also to include bromegrass, einkorn, and oat (5). Hagborg (19) proposed two new formae speciales, f. sp. hordei-avenae and f. sp. cerealis, using pathogenicity on oat as a criterion to distinguish these strains from the previously described f. sp. hordei and f. sp. undulosa. Wallin and Reddy (42) proposed a new variety, var. phleipratensis, that was pathogenic only for timothy. Six races of X. translucens var. cerealis were described (41) based on injection inoculations into bromegrass and oat species. Fang et al. (16), reporting nonpathogenicity on oat, proposed merging $X$. translucens var. hordei and $X$. translucens var. hordei-avenae, and redefined $X$. translucens $\mathrm{f}$. sp. cerealis as strains naturally occurring on smooth bromegrass and quack grass. Dye and Lelliott (14) reported an overlap of host ranges between different pathovars. The five different pathogen names were, nevertheless, retained (44) and included in the International Society for Plant Pathology's (ISPP) accepted list of plant pathogenic bacteria (13) as X. campestris pv. cerealis, $X$. campestris pv. hordei, $X$. campestris pv. secalis, $X$. campestris pv. translucens, and $X$. campestris pv. undulosa. However, pathovar descriptions remain confused. According to Bradbury (7), the former $X$. campestris pv. hordei is an objective synonym of $X$. campestris pv. translucens. This recommendation was adopted when the ISPP accepted list was recently revised (45), but other definitions for the pathovars of the 'translucens group' remained the same. From a practical point of view and based on their current descriptions, $X$. translucens pv. cerealis strains are not easily distinguishable from $X$. translucens pv. undulosa.

The species $X$. oryzae pv. oryzicola and $X$. translucens pv. phleipratensis have been shown to be clearly different from other pathovars of the 'translucens group' $(33,34)$ and will not be discussed here. 
Previous studies on protein and fatty acid profiling of $X$. translucens strain collections either failed to delineate pathogenicity groups $(32,39,43)$ or represented a limited geographic area (3). Comparative studies of the molecular variations at an international level and in relationship with pathogenicity have not been carried out previously. Visual analysis of protein electrophoresis showed differences between profiles (3), but analysis of a larger number of strain revealed that they cluster together (39). In fact, these five pathovars could not be differentiated by DNA hybridization (39), serological methods $(4,10)$, or fatty acid profiling $(32,43)$, although differences in host range and aggressiveness have been clearly demonstrated $(2,8,11,24)$.

Recent studies on population genetics using probes containing either $16+23 \mathrm{~S}$ rRNA or $a v r$ gene (pBSF2) sequences showed a clonal population structure in which neopathotype strains for $X$. translucens pv. cerealis, $X$. translucens pv. hordei, and $X$. translucens pv. undulosa clustered in different groups (9). Strains pathogenic only to barley were different from strains pathogenic to both barley and wheat. Using probes pIJ3225 and pI10, encoding for Hrp functions and xanthan production, respectively, Alizadeh et al. (1) reached similar conclusions. This clonal structure might have resulted from hostpathogen coevolution $(1,18)$. Nevertheless, if restriction fragment length polymorphism (RFLP) data were consistent with each other, though differences were observed according to the probe used, the discrepancy between these data and earlier studies using other fingerprinting methods raised the question of whether the pathovars of the 'translucens group' represent true biological entities.
The objective of the current study is to answer this question of whether these pathovars represent true biological entities. Xanthomonas strains recently collected worldwide from wheat and other Poaceae were analyzed and classified on the basis of their pathogenicity, previous characterization by RFLP using pathogenesis-related probes $(1,9)$, and the results of three fingerprinting techniques: gas chromatography of fatty acid methyl esters (FAME), sodium dodecyl sulfate-polyacrylamide gel electrophoresis (SDSPAGE) of proteins, and AFLP. AFLP is a new technique that combines the power of RFLP analysis with the flexibility of polymerase chain reaction (PCR)-based techniques. Using AFLP, Janssen et al. (20) have been able to differentiate highly related Xanthomonas strains, underlining the high potential of the technique for discrimination of strains at a subspecies level.

\section{MATERIALS AND METHODS}

Bacterial strains. Strains used in this study are listed in Table 1. All strains were lyophilized for long-term storage. Five ribotypes were previously characterized among a worldwide collection of BLS isolates from small grains (9), as well as three hrp clusters defined by RFLP analysis of a local Iranian collection of BLS isolates (1). On this basis, 68 representative strains were chosen, with particular attention to include diverse origins (18 countries, 14 host species, and seven pathovars). The majority of the strains were recent isolates. Pathotype and other strains were also included. Twenty-six of the strains were isolated from barley.

TABLE 1. Xanthomonas strains from small grains: Proposed pathovars, origin, and characteristics by pathogenicity and fingerprinting patterns

\begin{tabular}{|c|c|c|c|c|c|c|c|c|c|c|c|c|c|}
\hline \multirow{2}{*}{$\begin{array}{l}\text { Collection } \\
\text { number }\end{array}$} & \multirow{2}{*}{$\begin{array}{c}\text { Numbers in } \\
\text { other collections }{ }^{\mathrm{a}} \\
\end{array}$} & \multirow{2}{*}{$\begin{array}{c}\text { Pathovar name } \\
\text { proposed at isolation }\end{array}$} & \multirow[b]{2}{*}{ Host } & \multicolumn{2}{|c|}{ Isolation } & \multirow{2}{*}{$\begin{array}{l}\text { Path. } \\
\text { group }^{\mathrm{b}}\end{array}$} & \multirow[b]{2}{*}{$\mathrm{MAb}^{\mathrm{c}}$} & \multirow[b]{2}{*}{ AFLP $^{\mathrm{d}}$} & \multirow[b]{2}{*}{ FAME $^{\mathrm{e}}$} & \multirow[b]{2}{*}{$\operatorname{SDS}^{f}$} & \multirow[b]{2}{*}{$h r p^{g}$} & \multirow[b]{2}{*}{$a v r^{\mathrm{h}}$} & \multirow[b]{2}{*}{ rRNA } \\
\hline & & & & Date & Country & & & & & & & & \\
\hline \multicolumn{14}{|c|}{ Xanthomonas translucens pv. undulosa } \\
\hline $\mathrm{UPB}^{\mathrm{j}} 469^{\mathrm{k}}$ & NCPPB2822 & secalis & Secale cereale & 1966 & United States & A & + & 1 & 6 & 2 & & 1 & 1 \\
\hline UPB954 & LMG5259 & translucens & Secale cereale & 1983 & United States & A & + & 1 & & & & 2 & \\
\hline UPB412 & & undulosa & Triticum aestivum & 1987 & Argentina & A & + & 1 & $\mathrm{smc}^{1}$ & 1 & & 2 & 2 \\
\hline UPB410 & & undulosa & Triticum aestivum & 1988 & Argentina & A & + & 1 & & & & 2 & 2 \\
\hline UPB633 & & undulosa & Hordeum vulgare & 1988 & Mexico & A & + & 1 & & & & 2 & 2 \\
\hline UPB644 & & undulosa & Triticum aestivum & 1988 & Zambia & A & + & 1 & & & & 2 & 2 \\
\hline UPB675 & $10 X^{m}$ & translucens & Secale cereale & 1989 & South Africa & $\mathrm{A}^{+* *}$ & + & 1 & & & & 1 & 1 \\
\hline UPB685 & $321^{\mathrm{n}}$ & cerealis & Triticum aestivum & 1984 & Iran & A & + & 1 & & & & 1 & 1 \\
\hline UPB808 & IBLS33 & cerealis & Aegilops sp. & 1990 & Iran & A & + & 1 & & 1 & $2 \mathrm{~A}$ & & \\
\hline UPB834 & IBLS34 & cerealis & Aegilops sp. & 1990 & Iran & A & + & 1 & 3 & 1 & $2 \mathrm{~A}$ & & \\
\hline UPB840 & IBLS43 & cerealis & Sclerochloa dura & 1990 & Iran & A & + & 1 & 3 & 2 & $2 \mathrm{~A}$ & & \\
\hline UPB868 & IBLS39 & cerealis & Hordeum maritimum & 1990 & Iran & $\mathrm{A}^{\frac{\hbar}{2}}$ & + & 1 & 3 & 1 & $2 \mathrm{~B}$ & 2 & \\
\hline UPB922 & IBLS21 & cerealis & Triticum aestivum & 1988 & Iran & A & + & 1 & 3 & 1 & 2B & 1 & \\
\hline UPB928 & IBLS37 & cerealis & Bromus sp. & 1990 & Iran & A & + & 1 & 3 & 2 & $2 \mathrm{~A}$ & & \\
\hline UPB930 & IBLS24 & cerealis & Triticum aestivum & 1990 & Iran & A & + & 1 & 3 & 1 & $2 \mathrm{~A}$ & & \\
\hline UPB933 & IBLS27 & cerealis & Triticum aestivum & 1990 & Iran & A & + & 1 & 3 & 1 & $2 \mathrm{~A}$ & & \\
\hline UPB936 & IBLS41 & cerealis & Lolium strictum & 1990 & Iran & A & + & 1 & 3 & 1 & $2 \mathrm{~A}$ & & \\
\hline UPB939 & IBLS11 & cerealis & Hordeum vulgare & 1990 & Iran & A & + & 1 & 3 & 1 & $2 \mathrm{~B}$ & & \\
\hline UPB941 & IBLS30 & cerealis & Triticum aestivum & 1989 & Iran & A & + & 1 & 3 & 3 & $2 \mathrm{~B}$ & & \\
\hline UPB955 & LMG888 & undulosa & Triticum aestivum & 1969 & Canada & A & + & 1 & & & & 1 & \\
\hline $\mathrm{UPB} 443^{\mathrm{k}}$ & LMG892 & undulosa & Triticum durum & 1966 & Canada & $\mathrm{A}^{\text {क** }}$ & + & 1 & 3 & 2 & $2 \mathrm{~B}$ & 1 & 1 \\
\hline UPB482 & & undulosa & Triticum durum & 1988 & Pakistan & A & + & 1 & 3 & 1 & & 1 & 1 \\
\hline UPB804 & IBLS31 & cerealis & Triticum aestivum & 1990 & Iran & A & + & 1 & 3 & 3 & $2 \mathrm{~A}$ & & \\
\hline UPB869 & IBLS44 & cerealis & Heterantelium sp. & 1990 & Iran & A & + & 1 & 3 & 2 & $2 \mathrm{~A}$ & & \\
\hline UPB876 & & undulosa & Triticum aestivum & 1991 & Malagasy Rep. & A & + & 1 & 3 & 1 & & 1 & \\
\hline UPB932 & IBLS26 & cerealis & Triticum aestivum & 1990 & Iran & A & + & 1 & 3 & 1 & 3 & & \\
\hline UPB934 & IBLS28 & cerealis & Triticum aestivum & 1989 & Iran & A & + & 1 & 3 & 1 & $2 \mathrm{~A}$ & & \\
\hline
\end{tabular}

${ }^{a}$ NCPPB: National Collection of Plant Pathogenic Bacteria, Harpenden, United Kingdom; LMG: Laboratorium voor Microbiologie Gent Culture Collection, Gent, Belgium; IBLS: Iranian strains of bacterial leaf streak of cereals, and GXC strains, Alizadeh, Iran; and Cb: CIMMYT bacteria, Duveiller, Mexico.

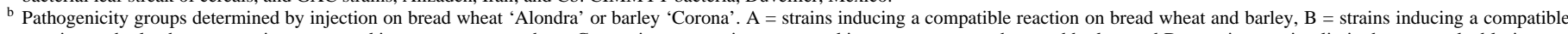
reaction on barley but not causing water-soaking symptoms on wheat, $\mathrm{C}=$ strains not causing water-soaking symptoms on wheat and barley, and $\mathrm{D}=$ strains causing limited water-soaked lesions on bread wheat and barley. Strains marked by * infected at least one of the six bromegrass species tested. Strains marked by ${ }^{\ddagger}$ produced translucent streaks and water-soaked lesions on at least one of the oat cultivars Adamo, Balmoral, or Wilmo.

${ }^{c}$ Reaction of strain by indirect immunofluorescence as described in Bragard et al. (9) using rat monoclonal antibody AB3-B6: $+=$ positive reaction and $-=$ negative reaction

d Cluster numbers determined by UPGMA analysis of Dice similarity coefficients derived from AFLP analysis.

e Cluster numbers determined by UPGMA analysis of Euclidian distances calculated from fatty acid methyl ester (FAME) data.

${ }^{\mathrm{f}}$ Cluster numbers determined by UPGMA analysis of Pearson coefficient calculated from sodium dodecyl sulfate-polyacrylamide gel electrophoresis (SDS-PAGE) profiles.

g Restriction fragment length polymorphism (RFLP) groups as previously published by Alizadeh et al. (1).

${ }^{\text {h }}$ RFLP groups determined using previously published data (9) and complementary profiles.

i Ribotypes as previously published (9) or as determined in this study.

j UPB: Unité de Phytopathologie bacterial strain collection, UCL, Louvain-la-Neuve, Belgium.

${ }^{k}$ Pathovar neopathotype strain.

${ }^{1} \mathrm{smc}=$ single member cluster

${ }^{\mathrm{m}}$ Smith, South Africa.

${ }^{n}$ Rahimian, Iran.

${ }^{\circ}$ Sands, United States.

p Miyajima, Japan.

${ }^{\mathrm{q}}$ Mehta, Brazil. 
RFLP analysis. Since few of these strains had been tested previously by RFLP, complementary RFLP analyses were performed on strains UPB634, UPB787, UPB820, UPB868, UPB906, UPB907, UPB916, UPB922, UPB938, UPB948, UPB949, UPB953, and UPB954 using either the pBSF2 DNA probe or the $16+23 \mathrm{~S}$ rRNA probe or both (Table 1). All procedures were identical to those previously described (9).

Immunofluorescence. Each strain was tested by indirect immunofluorescence. An aqueous cell suspension (30 $\mu$ l of approximately $10^{5} \mathrm{CFU} / \mathrm{ml}$ ) was air-dried on a multi-windows slide (Biomérieux, Charbonnière-les-bains, France). Immunofluorescence was performed as described previously (12) using two different rat monoclonal antibodies, AB3-B6 and BC7-C1 (10). For each strain, three repetitions were performed per antibody, and results were compared with a negative and a positive control (UPB438 and UPB443, respectively).

Pathogenicity tests. The pathogenicity of all strains was tested by infiltration of a bacterial suspension into three-leaf-stage seedlings grown in an air-conditioned greenhouse at $20 / 17^{\circ} \mathrm{C}$, day/night temperatures, under a 14-h photoperiod. Ten plants per cultivar and per strain were inoculated. Each strain was inoculated on Triticum aestivum cv. Alondra, Hordeum vulgare cv. Corona, and Avena sativa cv. Alfred. Neopathotype or selected strains were tested on nine oat cultivars (Adamo, Alfred, Balmoral, Evita, Johanna, Medusa, Poney, Tornado, and Wilmo) and 11 bromegrass species (Bromus arvensis, B. catharticus, B. commutatus, $B$. diandrus, B. erectus, B. inermis, B. lanceolatus, B. rubens, B. hordaceous, B. secalinus, and B. sterilis; Botanical Garden, Meise, Belgium) (Table 1).
Ten repetitions were performed for each strain-host combination. The culm was inoculated by injecting $0.1 \mathrm{ml}$ of a bacterial suspension into sterile physiological water $(\mathrm{NaCl} 0.85 \%)$ and adjusted to $10^{6} \mathrm{CFU} / \mathrm{ml}$ by spectrophotometry. Plants were incubated for 5 days in a dew chamber (95\% relative humidity or higher) for $12 \mathrm{~h}$ at $24^{\circ} \mathrm{C}$ (days) and $12 \mathrm{~h}$ at $17^{\circ} \mathrm{C}$ (nights), before being returned to the previous growing conditions. Special handling precautions were taken with strains: all inoculation materials were autoclaved after experiments. Inoculated plants were grown in deep plastic containers, watered from below, and placed in a closed humid chamber. Symptom development was assessed during the 12 days following inoculation at days 3, 5, 8, 10, and 12 .

SDS-PAGE of proteins. The procedures for cultivation of bacterial cultures, total protein extracts, and electrophoresis were performed as described by Vauterin et al. (36). Gels were scanned using a laser densitometer (LKB, Bromma, Sweden). Normalization of the gels and comparison of protein patterns were carried out using the GelCompar software package (version 3.0; Applied Maths, Kortrijk, Belgium) developed by Vauterin and Vauterin (38). The similarity between all pairs of traces was calculated using the Pearson product-moment correlation coefficient $(r)$ converted to percent values for convenience. Clustering was done by the unweighted pair group method using arithmetic averages (UPGMA). SDS-PAGE clusters were arbitrarily delineated at a minimum level of $r=0.89$.

FAME analysis. All strains used in the current study were grown on TSBA medium (3\% [wt/vol] Trypticase soy broth [BBL;

\begin{tabular}{|c|c|c|c|c|c|c|c|c|c|c|c|c|c|}
\hline \multirow{2}{*}{$\begin{array}{l}\text { Collection } \\
\text { number }\end{array}$} & \multirow{2}{*}{$\begin{array}{c}\text { Numbers in } \\
\text { other collections }\end{array}$} & \multirow{2}{*}{$\begin{array}{c}\text { Pathovar name } \\
\text { proposed at isolation }\end{array}$} & \multirow[b]{2}{*}{ Host } & \multicolumn{2}{|c|}{ Isolation } & \multirow{2}{*}{$\begin{array}{l}\text { Path. } \\
\text { group }^{\text {b }}\end{array}$} & \multirow[b]{2}{*}{$\mathrm{MAb}^{\mathrm{c}}$} & \multirow[b]{2}{*}{ AFLP $^{d}$} & \multirow[b]{2}{*}{ FAME $^{\mathrm{e}}$} & \multirow[b]{2}{*}{$\operatorname{SDS}^{f}$} & \multirow[b]{2}{*}{$h r p^{\mathrm{g}}$} & \multirow[b]{2}{*}{$a v r^{\mathrm{h}}$} & \multirow[b]{2}{*}{ rRNA $^{\mathrm{i}}$} \\
\hline & & & & Date & Country & & & & & & & & \\
\hline UPB513 & $\mathrm{Cb} 4$ & undulosa & Triticum aestivum & 1987 & Mexico & $\mathrm{A}^{* * *}$ & + & 1 & 3 & 2 & $2 \mathrm{~B}$ & 2 & 2 \\
\hline UPB522 & $\mathrm{Cb} 28$ & undulosa & Triticum aestivum & 1987 & Mexico & 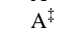 & + & 1 & 3 & $\mathrm{smc}$ & $2 \mathrm{~B}$ & 2 & 2 \\
\hline UPB681 & $26 X^{\mathrm{m}}$ & translucens & Triticum durum & & South Africa & A & + & 1 & 3 & 2 & & 1 & 1 \\
\hline UPB727 & & undulosa & Triticosecale & 1989 & Ethiopia & $\mathrm{A}$ & + & 1 & 3 & 1 & $2 \mathrm{~A}$ & 1 & 1 \\
\hline UPB729 & & undulosa & Triticum durum & 1989 & United States & A & + & 1 & 3 & 1 & & 1 & 1 \\
\hline UPB803 & IBLS32 & cerealis & Aegilops sp. & 1989 & Iran & $\mathrm{A}$ & + & 1 & 3 & 2 & $2 \mathrm{~A}$ & & \\
\hline UPB634 & & undulosa & Hordeum vulgare & 1988 & Mexico & A & + & 1 & 6 & 2 & & 2 & \\
\hline UPB878 & IBLS35 & cerealis & Aegilops sp. & 1990 & Iran & $\mathrm{A}^{\frac{7}{*}}$ & + & 3 & 1 & 2 & $2 \mathrm{~B}$ & & \\
\hline UPB733 & & undulosa & Triticosecale & 1989 & Peru & A & + & $\mathrm{smc}$ & 3 & 1 & & 2 & 2 \\
\hline \multicolumn{14}{|c|}{ Xanthomonas translucens pv. translucens } \\
\hline UPB906 & IBLS8 & hordei & Hordeum vulgare & 1990 & Iran & $\mathrm{B}^{+}$ & + & 2 & 2 & 1 & 1 & 3 & 4 \\
\hline UPB820 & IBLS2 & hordei & Hordeum vulgare & 1990 & Iran & B & + & 2 & 3 & 1 & 1 & 3 & \\
\hline UPB949 & LMG8279 & hordei & Hordeum vulgare & 1963 & New Zealand & B & + & 2 & & & & & 4 \\
\hline UPB867 & IBLS5 & hordei & Hordeum vulgare & 1990 & Iran & B & + & 3 & 2 & 1 & 1 & & \\
\hline UPB886 & IBLS40 & hordei & Hordeum maritimum & 1990 & Iran & $\mathrm{B}$ & + & 3 & 2 & $\mathrm{smc}$ & 1 & & \\
\hline UPB890 & IBLS6 & hordei & Hordeum vulgare & 1990 & Iran & $\mathrm{B}$ & + & 3 & 2 & 1 & 1 & & \\
\hline UPB907 & IBLS9 & hordei & Hordeum vulgare & 1990 & Iran & B & + & 3 & 2 & 1 & 1 & & 4 \\
\hline UPB916 & $11: 15^{\circ}$ & translucens & Hordeum vulgare & & United States & $\mathrm{B}^{\ddagger}$ & + & 3 & 2 & 1 & 1 & & 4 \\
\hline UPB929 & IBLS14 & hordei & Hordeum vulgare & 1990 & Iran & B & + & 3 & 2 & 1 & 1 & & \\
\hline UPB 852 & IBLS4 & hordei & Hordeum vulgare & 1989 & Iran & $\mathrm{B}$ & + & 3 & 3 & $\mathrm{smc}$ & 1 & & \\
\hline UPB880 & & hordei & Hordeum vulgare & 1991 & Libya & $\mathrm{B}$ & + & 3 & 3 & 1 & & & \\
\hline UPB948 & LMG882 & hordei & Hordeum vulgare & 1962 & Canada & $\mathrm{B}$ & + & 3 & & & & & 4 \\
\hline UPB $953^{\mathrm{k}}$ & LMG876 & translucens & Hordeum vulgare & 1933 & Canada & B & + & 3 & & & & & 4 \\
\hline UPB684 & $631^{\mathrm{n}}$ & hordei & Hordeum vulgare & 1984 & Iran & $\mathrm{B}^{\ddagger}$ & + & 4 & 2 & & 1 & 3 & 4 \\
\hline UPB805 & IBLS16 & hordei & Hordeum vulgare & 1990 & Iran & $\mathrm{B}$ & + & 4 & 2 & 1 & 1 & & \\
\hline UPB814 & IBLS1 & hordei & Hordeum vulgare & 1990 & Iran & $\mathrm{B}$ & + & 4 & 2 & 1 & 1 & & \\
\hline UPB $458^{\mathrm{k}}$ & LMG737 & hordei & Hordeum vulgare & 1970 & India & $\mathrm{B}^{*}$ & + & 5 & 2 & 1 & 1 & 3 & 4 \\
\hline UPB787 & & translucens & Hordeum vulgare & 1990 & Paraguay & $\mathrm{B}$ & + & 5 & 2 & 1 & & 3 & 4 \\
\hline UPB545 & $\mathrm{Cb} 23$ & translucens & Hordeum vulgare & 1987 & Mexico & $\mathrm{B}$ & + & 5 & & & 1 & 3 & 4 \\
\hline UPB763 & $\mathrm{X} 31^{\circ}$ & translucens & Hordeum vulgare & & United States & B & + & 5 & & & 1 & 3 & 4 \\
\hline UPB938 & IBLS15 & hordei & Hordeum vulgare & 1990 & Iran & $\mathrm{B}$ & + & $\mathrm{smc}$ & 3 & 1 & 1 & & 4 \\
\hline \multicolumn{14}{|c|}{ Xanthomonas translucens pv. cerealis } \\
\hline $\mathrm{UPB} 453^{\mathrm{k}}$ & LMG679 & cerealis & Bromus inermis & 1941 & United States & $\mathrm{A}^{* *} *$ & + & 6 & 4 & $\mathrm{smc}$ & 3 & 4 & 3 \\
\hline UPB946 & LMG880 & cerealis & Hordeum vulgare & 1952 & Canada & $\mathrm{A}^{\text {क* } *}$ & + & 6 & & & & 4 & 3 \\
\hline UPB921 & GXC1 & cerealis & Bromus sp. & 1990 & Iran & A & + & $\mathrm{smc}$ & 1 & smc & 3 & 4 & \\
\hline UPB721 & $7717-82^{\mathrm{p}}$ & cerealis & Bromus inermis & 1984 & Japan & 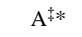 & + & $\mathrm{smc}$ & & & 3 & 4 & 3 \\
\hline \multicolumn{14}{|c|}{ Xanthomonas translucens pv. poae } \\
\hline $\mathrm{UPB} 454^{\mathrm{k}}$ & LMG728 & poae & Poa trivialis & 1978 & Switzerland & $\mathrm{C}$ & - & 7 & 4 & 1 & & 6 & 1 \\
\hline UPB951 & LMG584 & poae & Poa trivialis & 1979 & Switzerland & $\mathrm{C}$ & - & 7 & & & & 6 & \\
\hline \multicolumn{14}{|c|}{ Xanthomonas translucens pv. phleipratensis } \\
\hline $\mathrm{UPB} 441^{\mathrm{k}}$ & NCPPB 1837 & pheipratensis & Phleum pratense & 1966 & United States & $\mathrm{C}^{*}$ & - & $\mathrm{smc}$ & & & & 5 & 1 \\
\hline \multicolumn{14}{|c|}{ Xanthomonas translucens pv. undetermined } \\
\hline UPB920 & $\mathrm{GXC} 2$ & Undetermined & Lolium sp. & 1989 & Iran & $\mathrm{C}$ & - & smc & smc & 1 & & & \\
\hline UPB926 & GXC3 & Undetermined & Polypogon sp. & 1990 & Iran & $\mathrm{C}$ & - & $\mathrm{smc}$ & & 1 & & & \\
\hline Xanthomona & & & & & & & & & & & & & \\
\hline UPB670 & & Deviant & Triticum aestivum & 1990 & Brazil & $\mathrm{D}^{*}$ & - & 8 & 5 & $\mathrm{smc}$ & & 7 & 6 \\
\hline UPB758 & $9236^{\mathrm{q}}$ & Deviant & Triticum aestivum & 1990 & Brazil & $\mathrm{D}^{*}$ & - & 8 & 5 & 3 & & 7 & 6 \\
\hline
\end{tabular}


Becton Dickinson Microbiology Systems, Cockeysville, MD] and $1.5 \%$ [wt/vol] Bacto agar [Difco Laboratories, Detroit]) for 24 and $48 \mathrm{~h}$ at $28^{\circ} \mathrm{C}$. All strains were analyzed at least twice.

We followed the procedures proposed by Vauterin et al. (40) and Yang et al. (43). The Euclidian distance coefficient was calculated

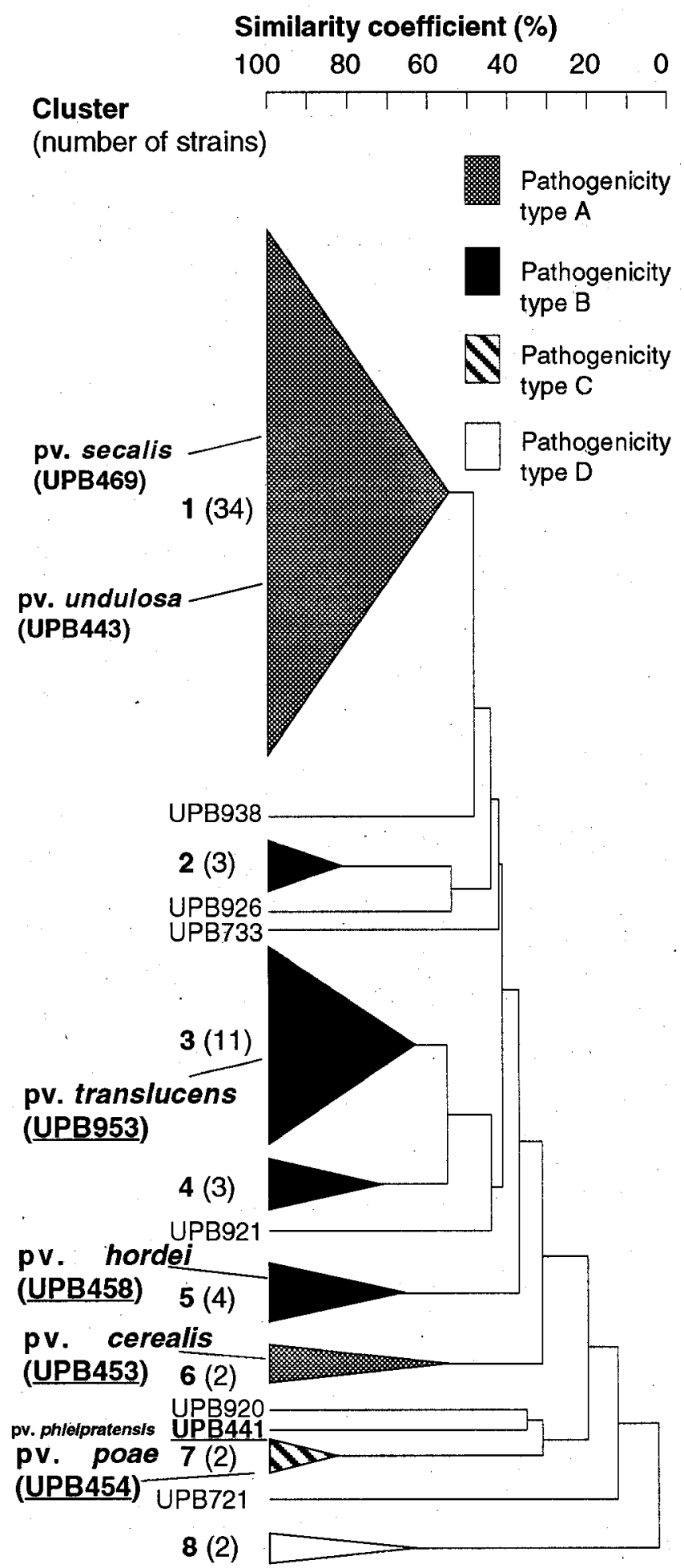

Fig. 1. Simplified dendrogram obtained by average linkage cluster analysis of AFLP patterns of 68 xanthomonad strains presented in Table 1. AFLP patterns were normalized and analyzed using GelCompar software version 3.0 (Applied Maths, Kortrijk, Belgium). Similarity between AFLP fingerprints was calculated using the Dice coefficient. Clusters were delineated at an arbitrary level of $r=0.55$. The shaded area indicates the strains belonging to the different pathogenicity types. Neopathotype strains (with their UPB cluster number underlined) are indicated in bold. between profiles, and clustering was achieved using UPGMA. FAME clusters were arbitrarily delineated at 8 Euclidian distance units.

AFLP analysis. An AFLP DNA fingerprinting technique (46) was used to characterize 68 xanthomonad strains. The AFLP method consists of (i) digestion of total cellular DNA with two restriction enzymes and ligation of restriction half-site specific adaptors to all restriction fragments; (ii) selective amplification of fragments with two PCR primers targeting adaptation and restriction site sequence; and (iii) electrophoretic separation of the PCR products on a $5 \%(\mathrm{wt} / \mathrm{vol})$ polyacrylamide/8.3 M urea gel.

The technique was applied as described by Janssen et al. (20) for Xanthomonas. The restriction enzymes ApaI and TaqI were used, as well as the corresponding primer, each with an additional selective 3'-terminal guanine. The resulting banding pattern contained approximately 30 to 50 PCR products in the size range 80 to $550 \mathrm{bp}$. Normalization of AFLP patterns and cluster analyses were done using the GelCompar software version 3.0 (Applied Maths). Similarity between AFLP fingerprints was calculated using the Dice coefficient, and clustering was achieved using UPGMA. Clusters were delineated at an arbitrary level of $r=0.55$.

\section{RESULTS}

Pathogenicity. Four pathogenicity types could be defined among all the strains studied based on their pathogenicity on barley and bread wheat (Table 1).

The first type (pathogenicity type A) was composed of strains able to produce a compatible reaction, characterized by greasy and water-soaked streaks covered by exudates, on the barley and wheat cultivars tested. On wheat, strains produced water-soaked areas within 3 days that developed into spots or streaks after 5 to 8 days. At day 8 , lesions showed a greasy appearance and were covered by numerous honey-like exudates. Lesions turned translucent and surrounding tissues turned yellow to light brown at day 10. Some of the leaves collapsed. After 10 days, lesions generally extended more than $5 \mathrm{~cm}$ around the inoculation point. Similar symptoms appeared on barley, except that exudate formation was delayed or restricted. Lesions on barley were often bordered by a yellow margin, and the size of water-soaked areas was smaller than that observed for wheat.

For the strains of pathogenicity type $\mathrm{B}$, the reaction on barley was similar to the reaction of strains of pathogenicity type A, but lesions were slightly longer and produced more exudate. In contrast, the reaction on wheat was essentially negative, with chlorotic symptoms restricted to inoculated areas at day 5 .

Pathogenicity type $\mathrm{C}$ was composed of strains not belonging to the 'translucens group' as defined earlier (35), but related to pathovars such as $X$. translucens pv. phleipratensis, $X$. translucens pv. poae, or strains from grasses that are undetermined at the pathovar level. Such strains always produced a negative reaction on all tested small grains.

Two unspeciated strains gave limited and water-soaked necrotic lesions on barley and wheat. They were placed in pathogenicity type D.

On oat, a greasy and water-soaked reaction, often associated with a subsequent collapse of infected leaf tissues, was considered as compatible. Water-soaking was observed by 5 days after inoculation. Later, water-soaked lesions were associated with yellowing or browning. Yellowing without water-soaking was considered as a negative reaction. Such a yellowing reaction occurred generally within 3 days and covered as much as $2 \mathrm{~cm}^{2}$, but sometimes was limited to small dots of $4 \mathrm{~mm}$ in diameter or less. The reaction of strains in the $X$. translucens pv. undulosa group was less aggressive on oat than that of strains in the $X$. translucens pv. cerealis group. Nevertheless, both groups were able to cause watersoaking on oat cultivars Balmoral, Poney, Tornado, and Wilmo.

On bromegrass species, elongated greasy streaks covered with bacterial exudates were observed and considered as a compatible 
response. Strains of $X$. translucens pv. cerealis and pv. undulosa produced a compatible reaction on $B$. commutatus, $B$. diandrus, $B$. inermis, and $B$. hordaceus, with some variability according to the bromegrass-strain combination and the number of plants showing symptoms. Browning was often associated with streaks, especially for $X$. translucens pv. undulosa and the undetermined pathovar strains. Xanthomonas spp. UPB758 and UPB670 produced numerous small water-soaked lesions (less than $5 \mathrm{~mm}$ in diameter) bordered by a necrotic margin on $B$. arvensis, B. commutatus, $B$. rubens, $B$. secalinus, and $B$. sterilis. Yellowing without watersoaking was considered to be a negative reaction.

Indirect immunofluorescence and RFLP profiles. All strains of pathogenicity types $\mathrm{A}$ and $\mathrm{B}$ gave a positive reaction with monoclonal antibody (MAb) AB3-B6 by indirect immunofluorescence. All of these strains also reacted with MAb BC7-CI, except strain UPB948. Bacterial cells stained with fluorescein isothiocyanate were clearly distinguishable on the dark background. The test was negative with other strains (from pathogenicity types $C$ and D).

Previous RFLP analyses were expanded to include additional strains. Using a $16+23 \mathrm{~S}$ rRNA probe from Escherichia coli, three different profiles were observed among the strains tested. Eight strains from pathogenicity type B gave a pattern similar to the neopathotype strain UPB458 (9). Five bands were observed per pattern, with 2.3- and 3-kb bands common to the 'translucens group' strains. However, strain UPB946, which was isolated from barley and is also pathogenic to wheat, showed a different profile, identical to the one obtained with $X$. translucens pv. cerealis neopathotype strain UPB453 (9). RFLP patterns obtained using the pBSF2 probe for strains UPB634, UPB820, UPB868, UPB906, UPB922, UPB951, and UPB954 matched (Table 1) patterns obtained in a previous study (9) for strains from the same pathogenicity type.

AFLP. Reproducibility was estimated on duplicate DNA extracts of neopathotype strains UPB441, UPB443, UPB453, UPB454, and UPB954 with a mean similarity coefficient of $r=$ 0.92 and by running 24 DNA extracts of the same strains with a mean similarity coefficient of $r=0.89$.

Eight clusters were delineated at a level of $r=0.55$ (Fig. 1). AFLP results were consistent with the pathogenicity types already described (Table 1). All strains from the major cluster (AFLP cluster 1) belong to pathogenicity type A and were shown to be pathogenic for barley and wheat. Most of the strains from this group were isolated from wheat, but strains isolated from triticale, rye, barley, and grasses are also present in this cluster.

Strains from clusters 2, 3, 4, and 5 were all isolated from barley and belonged to the pathogenicity type $\mathrm{B}$, with the exception of strain UPB878, which was isolated from goatgrass (pathogenicity type A).

Pathovar cerealis strains isolated from bromegrass and barley grouped into AFLP cluster 6. Strains of $X$. translucens pv. poae grouped into AFLP cluster 7, while the two South American Xanthomonas spp. isolated from bread wheat formed cluster 8 .

FAME analysis. The strains grouped mainly into two major clusters (FAME cluster 2, including 12 strains, and FAME cluster 3 , including 28 strains) and four minor clusters (FAME cluster 2, 4,5 , and 6, two strains each) at a level of 8 Euclidian distance units (Fig. 2; Table 1).

A relationship between the previously delineated pathogenicity types and FAME clusters was also observed. All strains from FAME cluster 2 belonged to pathogenicity type B. Among strains from FAME clusters 1, 3, 4, and 6,91\% belonged to pathogenicity type A, while only five strains were associated with pathogenicity type B (UPB820, UPB852, UPB880, and UPB938) and type C (UPB454).

FAME cluster 5 was composed of the two unspeciated strains UPB758 and UPB670, both falling in the pathogenicity type D. Strains UPB412 and UPB920 isolated from rye occurred as single member clusters.

Fatty acid patterns of all strains were compared with the commercial TSBA fatty acid database provided by MIDI (Microbial
ID Inc., Newark, DE) and the database generated by Yang et al. (43). Comparison of results obtained using different growth periods (data not shown) confirmed previous results $(32,43)$. With a $24-$ $\mathrm{h}$ growth period, only $64 \%$ of the strains were identified as belonging to the 'translucens group,' with the remainder of the strains matching $X$. campestris pvs. celebensis, phaseoli, phaseoli-fuscans, or malvacearum. In contrast, with a 48-h growth period, all type A, B, and C strains matched within the 'translucens group.' Xanthomonas spp. UPB758 and UPB670 were tentatively identified by FAME as $X$. campestris pv. ricini and $X$. campestris pv. vignicola.

The six major fatty acids (fatty acids with a mean percentage for fatty acid higher than 5\% for at least one FAME type) were 11:0 iso, 15:0 iso, 15:0 anteiso, 16:0 iso, 16:1 cis 7, and iso 17:1 cis 9. An interesting observation was that the fatty acid 15:0 iso was generally more abundant than fatty acid 16:1 cis 7 for strains of FAME cluster 3 (and pathogenicity type A) and of FAME cluster 5. In contrast, the ratio 15:0/16:1 cis 7 was less than 1 for strains of FAME cluster 2 (and pathogenicity type B).

SDS-PAGE. The reproducibility of the electrophoresis technique used was checked by running 20 protein extracts in at least two gels. In all cases, a level of reproducibility $(r)$ of more than 0.98 was achieved.

The profiles obtained with the 50 tested strains had a high level of similarity. Nevertheless, numerical analysis allowed the dis-

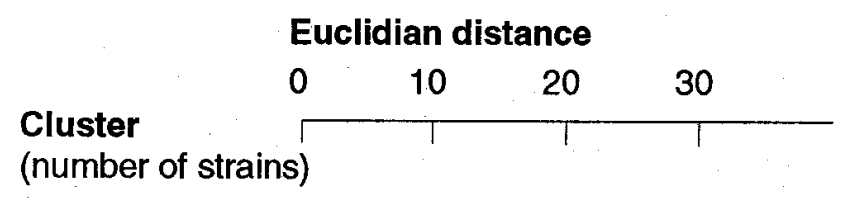

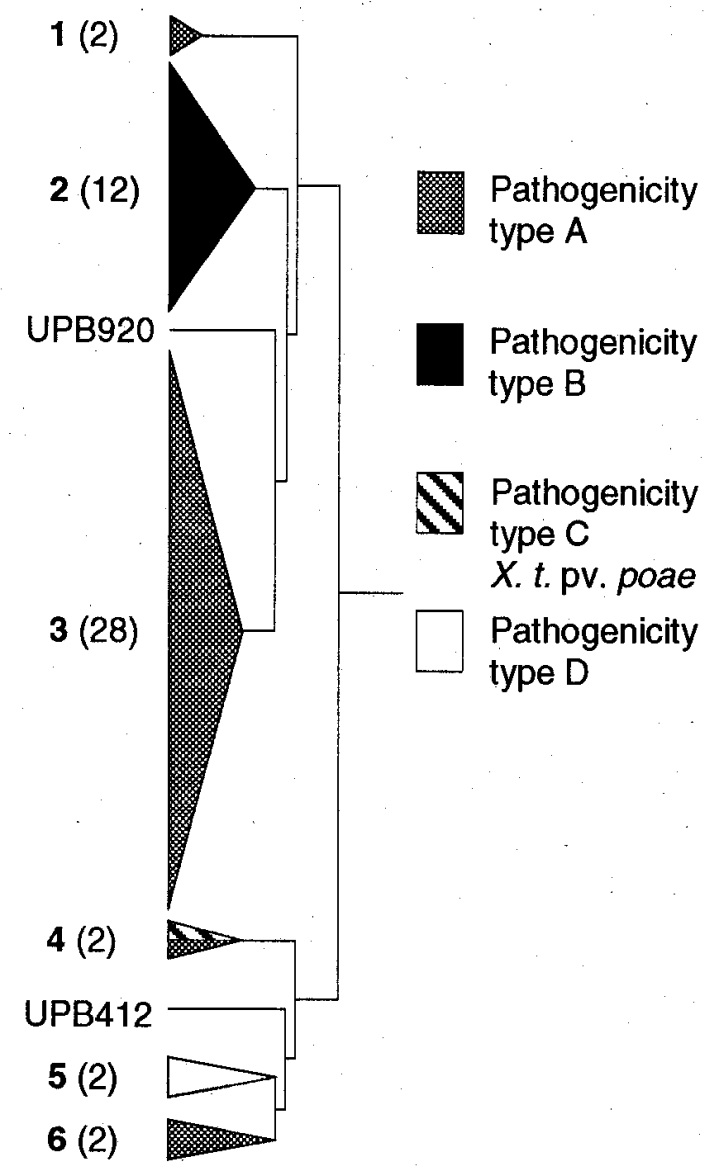

Fig. 2. Simplified dendrogram obtained by average linkage of Euclidian distance values between fatty acid methyl esters (FAME) profiles of 50 xanthomonads presented in Table 1 . FAME clusters were arbitrary delineated at 8 Euclidian distance units. The shaded area indicates the strains belonging to the different pathogenicity types. 
tinction of three clusters separated at $r=0.88$, revealing a low level of diversity across the clusters defined by other methods (Table 1). SDS-PAGE cluster 1 was a large and composite cluster including 16 strains of pathogenicity type A, 13 strains of pathogenicity type $\mathrm{B}$, and three strains of pathogenicity type C. SDSPAGE cluster 2 was composed of 10 strains, all from pathogenicity type A. SDS-PAGE cluster 3 was formed by two strains from pathogenicity type A and one Xanthomonas sp. (UPB758) from pathogenicity type D. The strains UPB453, UPB522, UPB852, and UPB921 (pathogenicity type A), and UPB670 (pathogenicity type D) occurred as single member clusters.

\section{DISCUSSION}

The 'translucens group,' sensu Vauterin et al. (39) is a group of closely related pathovars that used to be within the former species $X$. campestris. All of the 'translucens' strains used in this study were isolated from Poaceae and were pathogenic to barley. Most strains grouped together by FAME analysis at a level of 13 Euclidian distance units or by SDS-PAGE analysis at a level of $r=0.88$. They could not be differentiated by serology (Table 1) (10). The proposed species $X$. translucens (35) is larger than the 'translucens group' and includes several pathovars also isolated from Poaceae that are not pathogenic to small grains, such as $X$. translucens pv. phleipratensis or X. translucens pv. poae.

Nevertheless, at the pathovar level, the heterogeneity among strains pathogenic to small grains is real $(6,11,15,24)$. Pathogenicity of these bacteria has been described in terms of internal bacterial populations in leaf tissues $(15,24)$ and based on morphological reactions $(11,24)$ and microscopical study $(17)$. Some of the strains used in this work were previously characterized for their pathogenicity on barley and wheat and, for the Iranian strains, on Agropyron, Bromus, Lolium, and rye $(1,8,9)$. Since differential reactions have been reported (11), especially under suboptimum conditions (low inoculum level, low relative humidity, and resistant cultivar), pathogenicity tests were conducted at a high inoculum dose, on susceptible cultivars at a susceptible developmental stage (24), and at approximately $100 \%$ relative humidity. Under these conditions, two pathogenicity types (type A inducing a compatible reaction on wheat and barley and type B inducing a compatible reaction only on barley) were delineated based on tests using different cultivars. These biological entities correspond to the definition of $X$. translucens pv. undulosa and $X$. translucens pv. translucens, respectively. Three $X$. translucens pv. cerealis strains, including the neopathotype strain, gave the same compatible reaction on wheat and barley as pathogenicity type A strains. However, considering pathogenicity on oat and bromegrasses, they were somewhat different from type A strains. Another pathogenicity type was described for strains giving a negative reaction on both barley and wheat (type C) and for Xanthomonas spp. producing limited and different lesions on wheat and barley (type D).

There is a clear correlation between the pathogenicity types and results obtained by nucleic acid-based techniques. Among the eight clusters delineated by AFLP, each falls within a single pathogenicity type. The neopathotype strain for $X$. translucens $\mathrm{pv}$. undulosa was included in AFLP cluster 1 along with other type A strains. AFLP clusters 2, 3, 4, and 5 were composed of strains pathogenic only to barley (type B), including the neopathotype strains of $X$. translucens pv. translucens (cluster 3) and of $X$. translucens pv. hordei (cluster 5). X. translucens pv. cerealis formed cluster 6 . These $X$. translucens pv. cerealis strains appeared to be more closely related to $X$. translucens pvs. phleipratensis and poae, as well as to type $\mathrm{C}$ strains isolated from grasses. Strains considered as atypical and named previously "deviant pv. undulosa" appeared different from strains of the 'translucens group.' They clustered separately in AFLP cluster 8. This poses the question of whether they are opportunistic bacteria (31) or another Xanthomonas species.
Pathogenicity types correspond also to clusters obtained in previously published RFLP studies $(1,9)$. On the basis of RFLP analysis with a $16+23$ s rRNA probe from $E$. coli and a plasmid DNA probe from $X$. campestris pv. manihotis, which is homologous to the $a v r B s 3$ avirulence gene and required for pathogenicity on cassava plants (V. Verdier, G. Cuny, K. Assigbetse, J.-P. Geiger, and C. Boucher; poster presented at the 8th International Congress on Molecular Plant-Microbe Interacteractions, 1996), we reported clusters corresponding to different pathogenicity types (9). In the current study, the number of type B strains tested with the $16+23 \mathrm{~s}$ rRNA probe has been extended. Interestingly, all these strains showed the same RFLP profile with this probe, whereas strains isolated from barley and also pathogenic to wheat gave a different one, which was similar to the $X$. translucens pv. undulosa strains. This emphasizes the need to perform pathogenicity tests before naming a strain at the pathovar level. The clusters delineated by Alizadeh et al. (1) using two probes originating from $X$. campestris corresponded to those described by Bragard et al. (9). The abridged dendrogram produced by AFLP analysis shows the same structure as those produced by RFLP analyses. The real concordance between AFLP and RFLP results, as that observed previously with DNA-DNA hybridization (20), makes AFLP a choice tool not only for taxonomy, but also for epidemiological studies.

Although the nucleic acid-based techniques gave a similar general grouping, clusterings based on phenotypic expression of bacterial compounds like fatty acids (FAME) or proteins (SDS-PAGE) often reveal a different structure. This might be explained by the influence of environment on phenotype. Some genes related to pathogenicity are plant-inducible and not expressed in vitro $(25,27)$. Nevertheless, strains from each FAME cluster are, in general, of the same pathogenicity type and, consequently, allow identification at the pathovar level by this technique. This has also been shown recently for $X$. translucens pv. graminis and $X$. translucens pv. phlei (28).

On the basis of our results, we propose that (i) strains from pathogenicity type A and AFLP group 1 be considered as $X$. translucens pv. undulosa strains, (ii) strains from pathogenicity type B located in AFLP clusters 2, 3, 4, and 5 be considered as $X$. translucens pv. translucens strains, and (iii) strains from pathogenicity type A and AFLP group 6 be considered as $X$. translucens pv. cerealis strains. Pathotype C strains (pathovars phleipratensis or poae) were well separated by AFLP and are correctly named.

As shown by Mellano and Cooksey (22), transposon and chemical mutagenesis are both able to modify the $X$. translucens host range, hence changing the pathovar status of the strains. The AFLP data presented suggest such mutations have not occurred naturally among the strains tested. This is also shown by previously published RFLP data $(1,9)$ using pathogenicity-related probes and ribotyping. Linkage disequilibrium could explain such a discrepancy between data observed from the field and from laboratory experiments. It indicates also that, even if xanthomonads from small grains are phylogenetically, closely related bacteria, the pathovar and the pathogenicity type groupings still correspond to true biological entities. This fact underlines the need to study the phylogenetic relatedness of large numbers of recently isolated and well-characterized strains (37) by molecular techniques to develop a taxonomy that is useful to plant pathologists.

\section{ACKNOWLEDGMENTS}

This work was supported, in part, by a cooperative research program between International Center for Wheat and Maize Improvement and Belgian Agency for Cooperation. We thank V. Verdier (Orstom, Montpellier, France) for her help in DNA hybridizations and information about the pBSF2 probe; E. Duveiller (CIMMYT, El Batan, Mexico) for the bacterial strains and small grains samples he provided, as well as for his fruitful comments; and M. Mayo and I. Toth (SCRI, Dundee, Scotland) for reviewing the English. 


\section{LITERATURE CITED}

1. Alizadeh, A., Arlat, M., Sarrafi, A., Boucher, C. A., and Barrault, G. 1997. Restriction fragment length polymorphism analyses of Iranian strains of Xanthomonas campestris from cereals and grasses. Plant Dis. 81:31-35.

2. Alizadeh, A., Barrault, G., Sarrafi, A., Rahimian, H., and Albertini, L. 1995. Identification of bacterial leaf streak of cereals by their phenotypic characteristics and host range in Iran. Eur. J. Plant Pathol. 101:225-229.

3. Alizadeh, A., Dechamp-Guillaume, G., Sarrafi, A., Rahimian, H., and Barrault, G. 1996. Electrophoretic analysis of total and membrane proteins of Xanthomonas campestris pathovars, the causal agents of the leaf streak of cereals and grasses in Iran. J. Phytopathol. 144:97-101.

4. Azad, H., and Schaad, N. W. 1988. Serological relationships among membrane proteins of strains of Xanthomonas campestris pv. translucens. Phytopathology 78:272-277.

5. Bamberg, R. H. 1936. Black chaff disease of wheat. J. Agric. Res. 52: 397-417.

6. Boosalis, M. G. 1952. The epidemiology of Xanthomonas translucens (J.J. and R.) Dowson on cereals and grasses. Phytopathology 42:387-395.

7. Bradbury, J. F. 1986. Xanthomonas campestris pv. hordei. Pages 241242 in: Guide to Plant Pathogenic Bacteria. C.A.B. International Mycological Institute, Farnham Royal, United Kingdom.

8. Bragard, C., and Maraite, H. 1992. Pathogenic variations in Xanthomonas campestris pv. undulosa. Pages 807-812 in: Proc. Int. Conf. Plant Pathogenic Bact., 8th. M. Lemattre, S. Freigoun, K. Rudolph, and J. G. Swings, eds. INRA Edition, Paris.

9. Bragard, C., Verdier, V., and Maraite, H. 1995. Genetic diversity among Xanthomonas campestris strains pathogenic for small grains. Appl. Environ. Microbiol. 63:1020-1026.

10. Bragard, C., and Verhoyen, M. 1993. Monoclonal antibodies specific for Xanthomonas campestris bacteria pathogenic to wheat and other small grains, in comparison with polyclonal antisera. J. Phytopathol. 139:217-228.

11. Cunfer, B. M., and Scolari, B. L. 1982. Xanthomonas campestris pv. translucens on triticale and other small grains. Phytopathology 72:683-686.

12. Duveiller, E., and Bragard, C. 1992. Comparison of immunofluorescence and two assays for detection of Xanthomonas campestris pv. undulosa in seeds of small grains. Plant Dis. 76:999-1003.

13. Dye, D. W., Bradbury, J. F., Goto, M., Hayward, A. C., Lelliott, R. A., and Schroth, M. N. 1980. International standards for naming pathovars of phytopathogenic bacteria and a list of pathovar names and pathotype strains. Rev. Plant Pathol. 59:153-168.

14. Dye, D. W., and Lelliott, R. A. 1974. Xanthomonas Dowson 1939. Pages 243-249 in: Bergey's Manual of Determinative Bacteriology, 8th ed. R. E. Buchanan and N. E. Gibbons, eds. The Williams \& Wilkins Co., Baltimore.

15. El-Banoby, F. E., and Rudolph, K. W. E. 1989. Multiplication of Xanthomonas campestris pvs. secalis and translucens in host and non-host plants (rye and barley) and development of watersoaking. EPPO (Eur. Mediterr. Plant Prot. Organ.) Bull. 19:104-111.

16. Fang, C. T., Allen, O. N., Riker, A. J., and Dickson, J. G. 1950. The pathogenic, physiological and serological reactions of the form species of Xanthomonas translucens. Phytopathology 40:44-64.

17. Ferrauge, A.-P., and Maraite, H. 1994. Light and transmission electron microscopical study of the interactions between Xanthomonas campestris pv. translucens and pv. undulosa on wheat, barley and oat. Pages 813-818 in: Proc. Int. Conf. Plant Pathogenic Bact., 8th. M. Lemattre, S. Freigoun, K. Rudolph, and J. G. Swings, eds. INRA Edition, Paris.

18. Gabriel, D. W., Hunter, J. E., Kingsley, M. T., Miller, J. W., and Lazo, G. R. 1988. Clonal population structure of Xanthomonas campestris and genetic diversity among citrus canker strains. Mol. Plant-Microbe Interact. 1:59-65

19. Hagborg, W. A. F. 1942. Classification revision in Xanthomonas translucens. Can. J. Res. 20:312-326.

20. Janssen, P., Coopman, R., Huys, G., Swings, J., Bleeker, M., Vos, P., Zabeau, M., and Kersters, K. 1996. Evaluation of DNA fingerprinting method AFLP as a new tool in bacterial taxonomy. Microbiology 142: 1881-1893.

21. Jones, L. R., Johnson, A. G., and Reddy, C. S. 1917. Bacterial blight of barley. J. Agric. Res. 11:625-643.

22. Mellano, V., and Cooksey, D. A. 1988. Development of host range mutants of Xanthomonas campestris pv. translucens. Appl. Environ. Microbiol. 54:884-889.

23. Milus, E. A., and Chalkley, D. B. 1994. Virulence of Xanthomonas campestris pv. translucens on selected wheat cultivars. Plant Dis. 78:612-615.

24. Milus, E. A., and Mirlohi, A. F. 1994. Use of disease reactions to iden- tify resistance in wheat to bacterial streak. Plant Dis. 78:157-161.

25. Osbourn, A. E., Barber, C. E., and Daniels, M. J. 1987. Identification of plant-induced genes of the bacterial pathogen Xanthomonas campestris pathovar campestris using a promoter-probe plasmid. EMBO (Eur. Mol. Biol. Organ.) J. 6:23-28.

26. Reddy, C. S., Godkin, J., and Johnson, A. G. 1924. Bacterial blight of rye. J. Agric. Res. 28:1039-1040.

27. Schulte, R., and Bonas, U. 1992. The expression of hrp gene cluster from Xanthomonas campestris pv. vesicatoria that determines pathogenicity and hypersensitivity on pepper and tomato is plant-inducible. $\mathbf{J}$. Bacteriol. 174:815-823.

28. Sletten, A. 1996. Rapid identification of Xanthomonas campestris pv. graminis and $X$. c. pv. phlei by fatty acid profiling. J. Phytopathol. 144: 321-324.

29. Smith, E. F., Jones, L. R., and Reddy, C. S. 1919. The black chaff of wheat. Science 50:48

30. Stall, R. E., and Civerolo, E. L. 1991. Research relating to the recent outbreak of citrus canker in Florida. Annu. Rev. Phytopathol. 29:399-420.

31. Stall, R. E., and Minsavage, G. V. 1990. The use of hrp genes to identify opportunistic xanthomonads. Pages 369-374 in: Proc. Int. Conf. Plant Pathogenic Bact., 7th. Z. Klement, ed. Akademiai Kiado, Budapest.

32. Stead, D. E. 1989. Grouping of Xanthomonas campestris pathovars of cereals and grasses by fatty acid profiling. EPPO (Eur. Mediterr. Plant Prot. Organ.) Bull. 19:57-68.

33. Swings, J., van den Mooter, M., Vauterin, L., Hoste, B., Gillis, M., Mew, T. W., and Kersters, K. 1990. Reclassification of the causal agents of bacterial blight (Xanthomonas campestris pv. oryzae) and bacterial leaf streak (Xanthomonas campestris pv. oryzicola) of rice as pathovars of Xanthomonas oryzae (ex Ishyama 1922) sp. nov., nom. rev. Int. J. Syst. Bacteriol. 40:309-311.

34. van den Mooter, M., Steenackers, M., Martens, C., Gosselé, F., De Vos, P., Swings, J., Kersters, K., and De Ley, J. 1987. Differentiation between Xanthomonas campestris pv. graminis (ISPP list 1980), pv. phleipratensis (ISPP list 1980) emend., pv. poae Egli and Schmidt 1982, by numerical analysis of phenotypic features and protein gel electrophoregrams. J. Phytopathol. 118:135-156.

35. Vauterin, L., Hoste, B., Kersters, K., and Swings, J. 1995. The relationships within the genus Xanthomonas and a proposal for a new classification. Int. J. Syst. Bacteriol. 45:472-489.

36. Vauterin, L., Swings, J., and Kersters, K. 1991. Grouping of Xanthomonas campestris pathovars by SDS-PAGE of proteins. J. Gen. Microbiol. 137:1677-1687.

37. Vauterin, L., Swings, J., Kersters, K., Gillis, M., Mew, T. W., Schroth, M. N., Palleroni, N. J., Hildebrand, D. C., Stead, D. E., Civerolo, E. L., Hayward, A. C., Maraite, H., Stall, R. E., Vidaver, A. K., and Bradbury, J. F. 1990. Towards an improved taxonomy of Xanthomonas. Int. J. Syst. Bacteriol. 40:312-316.

38. Vauterin, L., and Vauterin, P. 1992. Computer-aided objective comparison of electrophoresis patterns for grouping and identification of microorganisms. Eur. Microbiol. 1:37-41.

39. Vauterin, L., Yang, P., Hoste, B., Pot, B., Swings, J., and Kersters, K 1992. Taxonomy of xanthomonads from cereals and grasses based on SDS-PAGE of proteins, fatty acid analysis and DNA hybridization. J. Gen. Microbiol. 138:1467-1477.

40. Vauterin, L., Yang, P., Hoste, B., Vancanneyt, M., Civerolo, E. L., Swings, J., and Kersters, K. 1991. Differentiation of Xanthomonas campestris pv. citri strains by sodium dodecyl sulfate-polyacrylamide gel electrophoresis of proteins, fatty acid analysis and DNA-DNA hybridization. Int. J. Syst. Bacteriol. 41:535-542.

41. Wallin, J. R. 1946. Seed and seedling infection of barley, bromegrass, and wheat by Xanthomonas translucens var. cerealis. Phytopathology 36:446-457

42. Wallin, J. R., and Reddy, C. S. 1945. A bacterial streak disease of Phleum pratense L. Phytopathology 35:937-939.

43. Yang, P., Vauterin, L., Vancanneyt, M., Swings, J., and Kersters, K. 1993. Application of fatty acid methyl esters for the taxonomic analysis of the genus Xanthomonas. Syst. Appl. Microbiol. 16:47-71.

44. Young, J. M., Dye, D. W., Bradbury, J. F., Panagopoulos, C. G., and Robbs, C. F. 1978. A proposed nomenclature and classification for plant pathogenic bacteria. N.Z. J. Agric. Res. 21:153-157.

45. Young, J. M., Sadler, G. S., Takikawa, Y., De Boer, S. H., Vauterin, L., Gardan, L., Gvozdyak, R. I., and Stead, D. 1996. Names of plant pathogenic bacteria 1864-1995. Rev. Plant Pathol. 75:721-763.

46. Zabeau, M., and Vos, P. 1993. Selective restriction fragment amplification: A general method for DNA fingerprinting. European Patent Office, publication $0534858 \mathrm{~A} 1$. 